\title{
Dictynna
}

Dictynna

Revue de poétique latine

$7 \mid 2010$

Varia

\section{Between Two Lives: Tiresias and the Law in Ovid's Metamorphoses}

\section{Kathryn Balsley}

\section{(2) OpenEdition \\ Journals}

\section{Electronic version}

URL: http://journals.openedition.org/dictynna/189

DOI: $10.4000 /$ dictynna.189

ISSN: 1765-3142

\section{Electronic reference}

Kathryn Balsley, «Between Two Lives: Tiresias and the Law in Ovid's Metamorphoses », Dictynna [Online], 7 | 2010, Online since 25 November 2010, connection on 10 September 2020. URL : http:// journals.openedition.org/dictynna/189; DOI : https://doi.org/10.4000/dictynna.189

\section{(ब) $(\Theta \Theta$}

Les contenus des la revue Dictynna sont mis à disposition selon les termes de la Licence Creative Commons Attribution - Pas d'Utilisation Commerciale - Pas de Modification 4.0 International. 


\title{
Between Two Lives: Tiresias and the Law in Ovid's Metamorphoses
}

\author{
Kathryn BALSLEY \\ University of Stanford \\ balsleyk@stanford.edu
}

"I, Tiresias, though blind, throbbing between two lives"-Eliot, The Wasteland

dumque ea per terras fatali lege geruntur

tutaque bis geniti sunt incunabula Bacchi,

forte Iovem memorant diffusum nectare curas

seposuisse graves vacuaque agitasse remissos

cum Iunone iocos et 'maior vestra profecto est,

quam quae contingit maribus' dixisse 'voluptas.'

illa negat. placuit quae sit sententia docti

quaerere Tiresiae: Venus huic erat utraque nota.

arbiter hic igitur sumptus de lite iocosa

dicta Iovis firmat: gravius Saturnia iusto

nec pro materia fertur doluisse suique

iudicis aeterna damnavit lumina nocte;

at pater omnipotens (neque enim licet inrita cuiquam

facta dei fecisse deo) pro lumine adempto

scire futura dedit poenamque levavit honore.

Dictynna - nº - 2010 
Now while these things were happening on earth by the decrees of fate, when the cradle of Bacchus, twice born, was safe, it chanced that Jove (as the story goes), while warmed with wine, put care aside and bandied good-humoured jests with Juno in an idle hour. "I maintain,"said he, "that your pleasure in love is greater than that which we enjoy." She held the opposite view. And so they decided to ask the judgment of wise Tiresias. He knew both sides of love...He therefore, taken up as the arbitrator for the playful dispute of the gods, took sides with Jove. Saturnia, they say, grieved more deeply than she should and than the issue warranted, and condemned her judge to perpetual blindness. But the almighty father (for no god may undo what another god has done) in return for his loss of sight gave Tiresias the power to know the future, lightening the penalty by the honour. ${ }^{1}$

The brief story of Tiresias' metamorphosis in the third book of Ovid's Metamorphoses into a woman, a blind man, and a prophet fits well with the other narratives of transformation in the third book. Like Cadmus (3.1-130), Actaeon (3.138-252), Semele (3.253-315), and Pentheus (3.511-733), Tiresias is punished for seeing something that he should not; like Semele and Echo (3.362-9), Tiresias is punished as a result of Juno's anger with Jupiter; and, finally, like Actaeon and Narcissus (3.402510), Tiresias' innocent action devolves into a permanent and life-changing punishment. Moreover, the story of Tiresias, the centerpiece of Book Three, presents a collapse of boundaries (male and female, mortal and divine, private and public) that is paradigmatic of all the narratives surrounding it. What is unique about the story of Tiresias, and what I shall focus on in this paper, is the use of allusions to contemporary legal realities in Rome to represent this breakdown of boundaries. By looking first at Ovid's legal language in its lexical contexts and then in its historical contexts, I shall argue that both the professionalization of jurisprudence at the end of Republic and the morality laws of Augustus, two legal developments which represent significant boundary crossings for the history of Roman law, are manifested in this brief scene.

I should begin by noting that the dominance of technical legal terminology in this passage is not initially surprising or problematic: there is no shortage of technical legal language used in paradoxical ways in much of Ovid's poetry, ${ }^{2}$ and Ovid, we know, did have a legal background which would contribute to his familiarity with legal terminology. ${ }^{3}$ What

1 - All translations, unless otherwise noted, are from F. J. Miller with my own modifications.

2 - E.g., Kenney (1969); Hopkinson (2001); VerSteeg and Barclay (2003). Hollis notes in his 1994 discussion of the Heroides, "this playing with legal concepts and terminology is characteristic of Ovid above all other Roman poets" (548).

3 - Ovid was trained in schools of Arellius Fuscus and Porcius Latro (Sen. Controv. 2.2.8-12) 
is surprising about the language in this scene, and what has not yet been acknowledged, is the deployment of increasingly specific legal language. ${ }^{4}$ We begin the passage with terms like doctus, sententia, and arbiter. These terms operate on both a colloquial and a technical plane, or what Kathleen Coleman has called 'popular' and 'precise' in her analysis of legal language in this passage. ${ }^{5}$ As the narrative progresses, though, we see terms like iudex, damnare, and inritus, words which are increasingly rigid and technical in their meaning. We have, in other words, language that is primarily appropriate for a legal and not a poetic context. I shall argue that the shift in this passage from common poetic uses to formal uses of specific words and phrases represents a move in this scene from a playful mock trial to a very real judgment and permanent punishment. The first part of this analysis, then, will explore the poetic contexts of Ovid's language in order to demonstrate this important use of increasingly specific legal terminology. For the second part, I shall situate the entire scene into its legal-historical contexts, explaining not just how Ovid uses his legal language but why he uses it the way he does. ${ }^{6}$

\section{Poetic Contexts}

Looking first at the poetic contexts, the narrative itself, we have in the beginning part of the passage the two terms sententia and doctus in close proximity (3.322). These two words can have a legal meaning but they also have a 'popular' meaning. ${ }^{7}$ Doctus, for example, means simply a learned or wise man (OLD 1), but it is also the vox propria of a jurisconsult. ${ }^{8}$ Sententia, likewise, operates on two registers: it can signal, more generally, an opinion $(O L D$ 1a) or it can represent a formal vote by a jury (4a), or even an authoritative decree, often one made by the Senate (5). ${ }^{9}$

and served on the tresviri capitales, a judicial panel which heard cases pertaining mostly to theft (Tris. 4.10.33-4).

4 - While any analysis of legal language in Ovid raises the question of whether Ovid is using this language in a specific, legal sense or simply engaging in the common parlance of educated Romans, I follow Kenney (1969) who argues that Ovid uses "untapped areas of terminology" (250-1) which differentiates his use of legal language from that found in his contemporaries like Propertius or Horace.

5 - Coleman (1990) 573.

6 - In this respect I follow Kristina Milnor who argues for a similar union of approaches in her discussion of Roman law in Latin literature: "instead of imagining the Roman legal system as something entirely external to Roman literature, we should see the two as arising from many of the same cultural concerns and constraints, and try to understand how changes in one may reflect and be reflected in changes in the other" $(2007,9)$.

7 - The clearly legal term lex in the first line of the passage (3.316) properly belongs to the previous story about Semele and the birth of Dionysus; it is these events that are governed by the law of fate (ea fatali lege geruntur). I do discuss this opening line in more detail at n. 19.

8 - Coleman, 573; citing Dig. 1.2.2.45-6.

9 - Indeed, when combined with placuit, the use of sententia here could allude to the language 
Coleman, noting the 'popular' and 'precise' meanings of sententia, asserts, "By employing this word, Ovid conveys the impression that he is using a popular term in rather a precise sense, to create an atmosphere" (573). While I agree that Ovid is aiming for a certain kind of atmosphere, I would suggest an opposite interpretation of how he achieves this. Ovid is using a popular term in both its precise and popular sense: precise for the subject matter at hand and popular for the poetic medium in which it is written. Jupiter is, after all, staging a mock trial to determine whether men or women enjoy sex more, and the pseudo-legal terminology at the beginning of the narrative establishes the legal setting of the scene while also remaining within the lexical boundaries of poetry. That is to say, Ovid uses the formal terminology associated with a civil trial, and Jupiter does everything according to judicial procedure, but it is clear that this is not a real trial nor that these terms have any legal valence. Jupiter performs justice, he does not practice justice. The use of the adjective iocosa (3.332), which undermines any technical or precise meaning of the term lis or the phrase arbiter sumptus (3.332), further supports such a reading of the text. ${ }^{10}$ We have, therefore, hints of legal realities in the first half of the passage achieved by the flexibility of legal terminology in Rome. The valence of terms like doctus or sententia is entirely dependent upon the medium and the context, and Ovid places these terms in a pseudo-legal setting, thus drawing on both potential registers, the popular and the precise, at the same time.

Jupiter's performance of justice, his mock trial, falls apart when Tiresias renders his sententia (dicta Iovis firmat, 3.333), and the collapse of the mock trial is marked by the legal terminology. Not only does Juno herself respond to the sententia as though it were a legally binding sententia, but the legal language at this point in the narrative also quickly becomes more formal and more fixed in its meanings. Tiresias is no longer arbiter but suus iudex, ${ }^{11}$ the judge of Juno, and iudex in Latin has a much more fixed legal meaning than does arbiter. ${ }^{12}$ Juno's punishment of Tiresias, moreover, is couched in specific legal phrasing: damnare (3.335) is a verb that,

used in senatus consulta: placere senatui; see Talbert (1984) 304; Cic. Att. 4.2.4. The phrase placuit sententia also appears in Propertius 2.9, and while we could interpret the phrase as operating in its 'popular' sense in Propertius, we should note that Propertius discusses in 2.7 the impact of Augustus' morality laws (which I discuss in the second part of this paper) on his relationship with Cynthia. Sententia in Propertius could thus perform a kind of double duty, serving primarily in its popular sense but also alluding to its more precise sense (as it does here in Ovid).

10 - Arbitrum sumere is a standard phrase in the Digest for the appointment of an adjudicator (Coleman, 574; citing Dig. 4.8.21.1, 4.8.33, 4.8.50, 10.2.47, 10.2.52.2, 33.3.4).

11 - Cf. the use of sui iudicis here to the description of the Golden Age in Book One: nec supplex turba timebant/ iudicis ora sui (1.92-3). In both cases iudex has a negative connotation for the person being judged.

12 - Arbiter can mean both a witness $(O L D 1)$ and a specially chosen moderator for a civil case (2). 
in its primary context, has only a strict legal sense. ${ }^{13}$ The adjective inritum (3.336) as well, which is used to describe Jupiter's inability to undo Juno's punishment, also has a primary legal meaning. ${ }^{14}$ Finally, we end the passage with an example of standard legal formulae: poenam levavit (3.338). Coleman offers a nice analysis of the use of this phrase (574):

Poenam leuare also has a technical flavour, being a set phrase for reducing penalties; the point here is that poenam explodes the pretence of the entire judicial scenario: the gods are above manmade law, and a penalty is imposed on the very person they appointed to pronounce judgement. While a Roman judge who betrayed partiality could in turn suffer legal action, Tiresias' conscientious verdict here is above reproach: he is the innocent victim of a deity who is a bad loser.

We can clarify Coleman's points even further: the pretense of the scenario, the mock trial Jupiter stages, is destroyed by the specificity of the language, and the legal terminology Ovid uses in this scene has taken us from a performance of justice to a practice of injustice.

While justice as a whole is a major concern of the Metamorphoses, we see with the dominance of technical legal terminology in this scene a keen interest in the formal, procedural elements of justice. Jupiter attempts to ensure a just decision by couching his actions in formulaic language, and yet a serious injustice still occurs and the security of justice guaranteed by adherence to procedure is completely subverted. In using a Roman system of justice, Jupiter destroys it. The passage moves from lex fatalis to lex Romana and then finally to lex divina, but this broadening of justice systems is, in turn, inversely matched with the increasing specificity of Roman legal terminology. In trying to make the mock trial more Roman, Jupiter forces it to become less Roman and so less reliable as a justice system for a mortal like Tiresias.

It is possible to interpret this entire scene as another instance of Ovid depicting the divine world as a Roman world. We have, for example, a striking parallel in the beginning of the poem when Jupiter assembles a council of the gods to narrate the story of Lycaon's punishment (1.163248). Much like the Tiresias myth, legal language and allusions to contemporary Roman government fill Lycaon's story and the description of the concilium deorum. Indeed, this opening narrative reads in many ways like a maiestas trial in the Roman Senate and we can find allusions within

$13-T L L$ v. $1.1233-1425$.

14 - OLD (1) inritus: not ratified or valid, null and void. Coleman also notes that "inritus denotes what is without legal sanction; hence inritum facere is the technical phrase for an act of annulment" (575). 
the story to contemporary developments in the Roman judicial process. ${ }^{15}$ But what is striking about the story of Tiresias, and what is also striking about the concilium deorum at the beginning of the Metamorphoses, is that this elaborate allusion to Roman law falls apart when put into practice. In both stories, Jupiter's adherence to Roman law and procedure (his use of legal language or Roman legal practices) proves to be unsustainable, and both stories end with a god employing lex divina in place of lex Romana. When examining, therefore, instances of Ovid's divine world as one that is Roman, I believe we must also ask ourselves how successfully Ovid's divine world acts or remains Roman. By isolating the legal language in the Tiresias story, and recognizing its increasing specificity, we realize that Jupiter is Roman in word only. His actions are those of a god.

The next question we must ask is whether this legal terminology is still significant when placed into the contexts of the Tiresias myth in ancient literature. To what extent is Ovid doing something new, something particularly Roman, and to what extent is he simply translating a Greek myth into Latin? I shall argue that Ovid does do something quite new with the myth insofar as he exploits the legal elements in the myth and draws attention to these legal elements in such a way that would have been new (and apparent) to his audience. As van Tress (2004) most recently has detailed, the allusive marker memorant (3.318) at the beginning of the story triggers comparisons to other versions of the Tiresias myth in the Hesiodic Melampodia and Callimachus Hymn 5. ${ }^{16}$ The version of the myth in the Melampodia, recorded in Eustathius' commentary of the Odyssey, is essentially the version we have in Ovid: Tiresias is

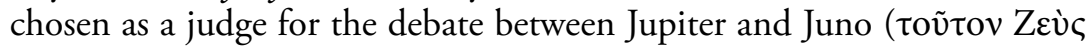

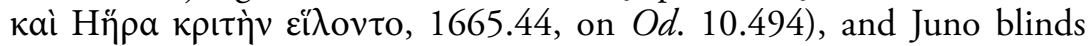
Tiresias when he decides in favor of Jupiter that women enjoy sex more than men. Jupiter then mitigates the punishment by giving Tiresias the gift of prophecy. The Tiresias myth in Callimachus' Hymn 5 is drastically different from the Hesiodic version and was most likely known to Ovid and his audience. ${ }^{17}$ In the Callimachean version of the myth, Tiresias accidentally sees Athena bathing and the goddess blinds him as punish-

15 - On the Roman allusions in Ovid's concilium deorum, see Feeney (1991); on reading the scene as a maiestas trial, see Balsley (forthcoming).

16 - I would like to add to that list, based on the work of O'Hara (1996), the Greek elegiac poem Tiresias by Sostratus as well. Sostratus presents six metamorphoses, which include Tiresias' judgment of the debate between Jupiter and Juno and of the beauty contest between Aphrodite and the Graces, both of which result in a metamorphosis For the full literary background of the Tiresias myth, see, most recently, Di Rocco (2007); more briefly, Barchiesi (2005) 171-2; and, most thoroughly, Ugolini (1995).

17 - On the relationship between Callimachus and Ovid, see, most recently, van Tress (2004); also, Tarrant (2002) 21-23; Barchiesi (1997) 39-43; Knox (1986). 
ment. When Tiresias' mother complains about the punishment, Athena sympathizes and says that she is bound by the laws of Cronus (Kpóvıo $\delta^{c}$ $\tilde{\omega} \delta \varepsilon \lambda \varepsilon \dot{\gamma} \gamma \mathrm{ov \tau \iota}$ vó

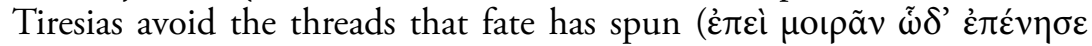

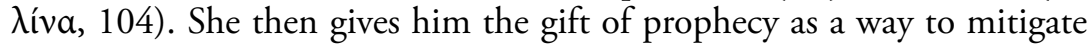
the punishment.

The use of legal terminology in Ovid's version of the myth, while suggested perhaps in the Hesiodic version (and the poem of Sostratus), seems to come most strongly from Callimachus. ${ }^{18}$ We have in Ovid the clear narrative framework of Hesiod and Sostratus (Tiresias punished after serving the role of judge), but Callimachus' careful observation of an over-arching justice system drives Ovid's version. Hera's assertion that the nomoi of Cronus and the threads of moira compel her to punish Tiresias as opposed to her blind rage - is meant to provide a kind of appeasement to Tiresias' mother; Juno has no choice but to punish Tiresias. In Ovid we have mention of such an over-arching framework with the opening phrase ea geruntur fatali lege (3.316), but the matters which lex fatalis governs are ambiguous and potentially problematic. ${ }^{19}$ Moreover, lex fatalis refers to the story that came before, and the use of a dum clause suggests that something other than fate will be driving the story of Tiresias. Ovid therefore replaces the divine nomoi and moira of Callimachus with the lex Romana Jupiter employs and, I would argue, allows the lex Romana to collapse in the face of lex divina (or, perhaps more accurately, ira deae). Jupiter's attempts to use Roman legal procedure to settle a trivial debate in a kind of mock trial are countered by Juno's irreversible punishment: he cannot make the facta of another god inrita. While Callimachus provides a recourse to divine law in order to offer consolation to mortals, Ovid offers three different kinds of lex (fatalis, Romana, and divina), all of which independently should provide a stable system of justice for mortals to rely upon, but, as the narrative makes clear, one system cannot co-exist with any of the others. ${ }^{20}$

18 - The story of Actaeon in the Metamorphoses (3.138-252) has, of course, the strongest narrative connections with Callimachus' version of the Tiresias myth. Ovid's story of Actaeon notably has the rare authorial comment on the nature of Actaeon's crime (3.141-2): at bene si quaeras, Fortunae crimen in illo, I non scelus invenies; quod enim scelus error habebat?

19 - The line does not have a clear antecedent: ea could refer to the birth of Bacchus, or the death of Semele, or the entire myth of Semele. We need to know what ea represents in order to know what fatalis lex represents. While Iiro Kajanto interprets the $e a$ as referring to the birth of the god (1961, 14-15), it is possible Ovid is asserting that the entire story of Semele has been governed by fate. Such an assertion would, of course, be problematic; we have just finished the story of Semele and very little of it seems to be up to fate. Indeed, the central driving force for the entire narrative is Juno's anger (3.259-72), and even the birth of Bacchus is more the result of Jupiter's divine intervention than any kind of fatalis lex.

20 - As Barchiesi (2005) notes in his commentary, "L'uso ricorrente di sfumature del linguaggio giuridico può essere visto come un pastiche anacronistico basato sulla realtà sociale romana, ma ha 
E. J. Kenney (1969) argues for a similar reinterpretation of a Callimachean version of a myth by Ovid in the story of Acontius and Cydippe in Heroides 20 and 21. Both characters employ legal terminology to describe Acontius' attempt to wed Cydippe, drawing attention to "the way in which he [Ovid] brings out and exploits a legal - really a pseudo-legal - situation which could be made, as in Callimachus' treatment it was not made, crucial in the motivation of the characters and the argumentation given to them in this controversia ethica" (Kenney, 259). In the story of Tiresias, Ovid also exploits the pseudo-legal situation, the germ of which we can see in the Callimachean version, and he makes this situation central to the motivation of the characters. Indeed, Jupiter's use of legal terminology gives Tiresias' sententia more weight than the situation merits, and Juno, in turn, responds to this decision with anger that befits the legal environment Jupiter has created. Unlike other versions of the Tiresias myth, Ovid manipulates and magnifies the legal aspects of the narrative, transitioning in this brief scene not only between allusions to Roman law and Roman law itself but also between different justice systems entirely. This manipulation and magnification of the legal potential in the myth of Tiresias is, as I shall argue next, indicative of the legal climate in which Ovid was writing.

\section{Historical Contexts}

Now that we have made clear how Ovid brings out the legal elements of the myth and how he uses increasingly specific legal language, I want to investigate why Ovid does this, a question which I think is not often asked of the legal terminology in Latin poets. In his work on the professionalization of law at the end of the Republic, Bruce Frier writes, "substantive law is a system of rules, while procedural law is a system of roles" (The Rise of the Jurists, xiv). Ovid's deployment of legal language in this story is largely centered upon the various roles Tiresias plays; with his final transition into iudex, Tiresias changes in this very brief scene from doctus to arbiter to iudex, terms of increasing specificity which also mark the shift from a mock trial judged by Tiresias to a real trial of Tiresias judged by Juno. Tiresias' metamorphosis of role (and its subsequent consequences) needs to be more carefully examined because it reflects a significant change in Roman judicial affairs. The very first role Tiresias adopts in this scene is doctus, the same term used of the jurisconsults who were aiding in the professionalization of Roman law during this time period. Tiresias is then called an arbiter, a term used to describe someone

anche l'effetto di sottolineare come il potere divino sia inconciliabile con gli usi giuridici del mondo umano" (173). 
who is a witness $(O L D 1)$ or a mediator with greater judicial discretion than a judge $(O L D 2) .{ }^{21}$ Finally, as noted above, Tiresias ends the scene as the judge, iudex, of Juno. Over a span of fifteen lines, Tiresias plays three very different legal roles and the instability of the terms Ovid uses reflects, as I shall argue, the instability of these specific roles themselves under Augustus as the law became professionalized.

To best understand the importance of Tiresias' roles and the valence of his sententia, I shall outline briefly the historical contexts for this passage, beginning with what exactly professionalization of law means. Frier still offers in my opinion the best summation of the legal scene at the end of the Republic (Frier, 272):

The jurists began to study and manipulate the materials of private law in a disciplined, rational fashion...Through their efforts, the intellectual content and social capacity of private law were markedly increased; and soon the discipline of law also became all but inaccessible to those not specially trained in it. To this extent, law was "professionalized" by being transformed into a self-consciously autonomous field of study.

One aspect of this professionalization is the level of objective analysis that is brought to the law. Alessandro Schiesaro writes that the jurists were "keen on generalizing abstractions which seek uniformity of explanation behind apparently disparate phenomena" $(2007,73)$. This objectivity turns law into what Frier describes as "an abstract body of norms" that results in a transition from rhetorically savvy orators and their case-oriented arguments to trained specialists who are unconcerned with the personage of the claimants (287). Cases are settled less by an appointed iudex, chosen from the roster of eligible men, who would appeal to a consilium for advice, and more by jurists whose responsa come to have the force of law under Augustus. Andrew Wallace-Hadrill sees this as a union of two forms of authority under Augustus: social authority and academic learning $(1997,14)$. Law, in other words, becomes professional and Augustus employs these professionals in his own regime. In this respect, Augustus' legal decrees and decisions reflect both his own political power and his personal control of scientia (Wallace-Hadrill, 16). ${ }^{22}$

21 - The specific meaning of arbiter in Roman law was a matter of debate for jurists. An arbiter could be chosen by the two parties involved who agreed to settle their disagreement through arbitration rather than summoning the praetor who would appoint a iudex (Cicero Pro Rosc. 4). In his discussion of the difference between arbitrium and iudicium, Cicero places emphasis on the discretion used with arbitrium by the arbiter (de Off. 111).

22 - The degree to which Augustus 'controlled' the jurists is unclear, particularly with regard to the issue of ius respondendi. This ius perhaps gave jurists the right to render responsa that were legally binding for judges but, as Kaius Tuori nicely puts it, "The significance, even the very existence of the ius respondendi is one of the many unsolved puzzles of Roman legal history" $(2004,295)$. We have vague and conflicting discussions of this right in Pomponius (Dig. 1.2.2.48-50), Gaius (Inst. 
When we turn back to the story of Tiresias, these changes to the legal system and to sources of legal authority nicely map onto the myth as presented by Ovid. Tiresias' shifting role, from jurist to mediator to judge, presents a challenge to the roles played by Juno and Jupiter. Tiresias is brought in as a legal expert for a kind of civil suit, but when he performs the defining action of his role, namely the rendering of his sententia, his role changes: he is no longer a doctus or an arbiter but a iudex, specifically the judge of Juno, and Juno reacts to Tiresias' judgment through a reassertion of her own role. Her reaction and her punishment move the trial from the mock, mortal plane created by Jupiter back to the divine plane. While Tiresias previously was the expert, and Jupiter and Juno the plaintiffs, Tiresias is now a mortal who can be judged, Juno is a goddess who can perform the judgment and the penalty, and Jupiter is a god bound by divine law to amend, but not undo, the action of another divinity. This is a significant destabilization; the roles that are so integral to Roman justice are upended once there is a divine presence. ${ }^{23}$ Jupiter seems content to let the doctus decide the matter, relinquishing any imperium he may have as a god, but Juno does not so easily concede. Once the sententia has been rendered by Tiresias, now labeled a iudex, Juno quickly asserts her own imperium, which easily trumps any temporary power granted to Tiresias.

There is a tension, therefore, in this scene between the judicial authority that is gained by virtue of a person's prominent role in society and that which is gained by virtue of a person's training or personal experience. The judgment of Tiresias can, in this respect, be read as an examination of the sources of auctoritas for Roman law. Jupiter, like Augustus, is the omnipotent lawgiver, the man who enforces law while also standing above it. Jupiter's auctoritas comes from his very position in the divine hierarchy, but he willingly surrenders this authority to Tiresias. Tiresias, in turn, has different sources for his own legal auctoritas. On the one hand, his knowl-

1.7), and Justinian (Inst. 1.2.8). The central debate is whether the ius actually existed and whether it was a special right granted by Augustus or if it was a continuation of a right held by all jurists to which Augustus added his imperial backing (Tuori, 329). The debate, of course, also reflects the larger debate in Roman history about the nature of Augustus and his principate (Tuori, 317): "The kind Augustus supported the jurists with altruistic motives and did not use the ius respondendi as a means to interfere with the law. In contrast, the corrupt Augustus usurped the free Roman jurisprudence and used it as a tool for his political aim, the total dominance over Roman society."

23 - Louden's analysis of the legal configuration in standard epic triangles in which "the sky father serves as judge over the hero, while the mentor deity can be seen as the hero's advocate or defense attorney, and the wrathful deity as a prosecuting attorney seeking punishment, or even the death, of the hero," is interestingly disrupted in Ovid's epic $(2005,91)$. While the Metamorphoses rarely employs this standard triangle, Ovid does seem to be aware of the epic function of Jupiter as judge (e.g. the story of Lycaon, our very first metamorphosis in the text) and plays with the idea, often collapsing roles. In this scene, for example, Jupiter relinquishes his epic role as judge and attempts to deny Juno her Virgilian role as the wrathful deity, but Jupiter must then take on the role of Tiresias' advocate and judge. 
edge, his role as doctus, gives him a special authority and this knowledge allows him to act as an arbiter, a mediator. On the other hand, while Tiresias can deliver his sententia from personal experience, any authority this sententia has ultimately comes from Jupiter. It is Jupiter who summons Tiresias and Jupiter who lays the groundwork of the pseudo-legal framework; Jupiter's own authority and Jupiter's readiness to recognize Tiresias' sententia as having any meaning support any authority Tiresias may have.

This tension also arises from the terminology Ovid uses to describe Tiresias and the roles he plays. In the poem itself, there is no problem with Ovid slipping between doctus, arbiter, and iudex to describe Tiresias in this brief passage; they all essentially label Tiresias as a person qualified to make a decision. In a legal setting, though, these terms have very significant and very different meanings. Each role brings with it its own specific kind of auctoritas. The jurist undergoes formal training and has specialized knowledge; the arbiter is chosen, and so legitimated or ratified, by the two parties who choose him; and the iudex has the implicit auctoritas of the formulae and procedure he upholds and enforces. Tiresias, of course, does not meet the legal requirements of these precise definitions: Tiresias is a doctus because he has been both a man and a woman not because he has undergone formal training; Tiresias is chosen by Jupiter to make a decision and not by Jupiter and Juno both; finally, Tiresias is in a mock trial, mimicking but not literally employing Roman legal procedure. Ovid's use of all three terms to describe one person rendering one sententia is almost cavalier from a legal standpoint. The poet threatens the distinctions jurists were making between such terms, removing boundaries between the poetic and legal uses of terms. We could, in fact, see a joke within these lines at the jurist's expense. As Cicero tells us in the Pro Murena (12), the jurists concerned themselves with these distinctions between arbiter and iudex - both terms appear in the Twelve Tables - and Cicero himself thought such a study was pedantic. In other words, only a doctus would care if Tiresias is an arbiter or a iudex.

The legal allusions in this scene are serious enough, but we cannot, therefore, ignore the comedic aspects of the narrative. Ovid presents, with all its legal trappings, the settling of a debate about the pleasures of sex. Even more comedic than the subject matter of the debate are the parties involved: the king of the gods, his wife, and a mere mortal whose expertise comes from his life experience of being a woman for a brief period of time. Any formality the scene may have is clearly undercut by its triviality, and the possible allusion to declamatory controversiae only emphasizes the 
comedic potential of the scene. ${ }^{24}$ Juno is said to have been upset nec pro materia (3.334), and while materia could of course simply refer to the matter at hand, the term is also used to describe topics of controversiae, the rhetorical exercises which argue "a particular side of an (often outlandishly) hypothetical law case" (Dugan, 17). ${ }^{25}$ If we pursue this second reading of materia, Juno becomes an untrained Roman who takes seriously the outrageous topics of controversiae.

The farcical elements of the scene become satirical when we consider a second important legal development, one which would not make the debate such an 'outlandishly' hypothetical law case but a reflection of real debates happening in Rome. This development would be the moral legislation of Augustus, the lex Iulia de maritandis ordinibus and the lex Iulia de adulteriis coercendis (18-17 BCE), which set up a new quaestio perpetua for the crimes of adultery and stuprum. ${ }^{26}$ The creation of these new laws regulating the personal lives of Romans required a fairly systematic discussion of 'moral' and 'immoral' sexual relations. While the jurists never had to consider the issue of who enjoyed sex more, men or women, they did have to define the status of women and determine whether sex with a certain woman could be construed as adultery. In other words, "it was the status of the woman rather than the man which defined a sexual act as adulterous" (Milnor, 2005, 150). The leges Iuliae also turned what had been a matter of domestic law into imperial law. Thomas Habinek summarizes the situation as follows $(1997,29)$ :

In effect, the Augustan "moral" legislation disembedded sexual behavior from its traditional familial context, where it had been regulated by forces of honor and shame, and instead described it as a freely chosen activity between legal persons, one subject to scrutiny and regulation in the public sphere.

A private matter which has been under the purview of the paterfamilias is now a public matter, with defendants charged and punished before the eyes of all. It is, in other words, a shift in justice systems. Private (and oftentimes unregulated) justice becomes public justice, subject to legal analysis and formulae. With the creation of a quaestio perpetua, the adultery laws are treated with the same weight as treason laws; a woman

24 - I should mention here the influence of mime on Ovid's works and the potential influence mime may have had on this particular scene, representing as it does a humorous take on the private lives of gods. On scenes from Ovid that can be traced to specific mimes, see Horsfall (1979) and Fantham (1983).

25 - For examples of materia, see Quint. Inst. 3.7.3; Tac. Dial. 35.4.

26 - On the moral legislation and representations of or reactions to the legislation in imperial literature, see most recently Milnor (2005) and McGinn (2001). 
accused of adultery has to be tried in public, in front of a standing jury court, with witnesses and evidence.

With this background in mind, the debate over Jupiter's casual comment about women enjoying sex more than men and his decision to bring in an 'expert' to settle the debate has a different significance for Ovid's Roman audience than the Hesiodic or Sostratean versions of the myth would have had for their contemporary audiences. As comical as the debate is in Ovid's Metamorphoses, similar kinds of debates are happening at this time in Rome with very real consequences for Roman citizens, especially women, and for the nature of Roman law. 27

This historical contextualization of the myth also causes us to reexamine Juno's anger over Tiresias' decision. In earlier versions of the myth, Juno's punishment seems to be simply in keeping with her characterization as an angry and impetuous divinity. In Ovid, with the heightened legal elements, Juno's reaction is more historically situated and legitimized. As noted before, Tiresias is an outsider, a person whose power comes from expertise and not status, and we can see how Juno's anger is not so much about the decision itself but the person who is able to make the decision. From Juno's perspective, a doctus has been permitted to render a decision on what would have been a private matter under Republican law; moreover, Jupiter, the pater omnipotens, has surrendered his judicial authority to an outsider. Juno's anger, within these contexts, seems quite reasonable and rational; her attitude towards the pleasures of sex is being debated and determined by two men, one of whom has no business being involved in the matter whatsoever, and the other of whom has permitted this man to render such an opinion.

This legal context can also, I think, offer a slightly different take on Juno's role in both this scene and the story immediately preceding this one, the death of Semele. As noted before, Tiresias' changing role threatens the traditional roles played Jupiter and Juno. Juno, in particular, is in a state of flux in this scene. She begins the narrative as Iuno, the Roman goddess who is sister and wife to Jupiter, with whom Jupiter bandied playful jokes (agitasse remissos/cum Iunone iocos, 3.319-20), but after Tiresias delivers his opinion she becomes Saturnia, who is characteristically gravius iusto (3.333). This transition from Iuno to Saturnia appears in the Semele narrative as well (3.253-315). In this story, the goddess makes her identity conditional upon the punishment of the young girl Semele, first labeling herself Iuno (si maxima Iuno/rite vocor, perdam, 3.264-5) and then declaring herself Saturnia (nec sum Saturnia, si non/ ab Iove mersa suo Stygias penetrabit in undas, 3.271-2). The two narratives

27 - The lex Iulia de adulteriis coercendis was the only special criminal lex about which the jurists wrote monographs, see Bauman (1980) 129; McGinn (1998) 246. 
are markedly similar: in both stories Juno punishes Jupiter for his dealings with mortals by punishing the mortal, and in both stories Juno is labeled Saturnia when she becomes angry and vengeful. While Hardie (1990) and Prauscello (2008) have both looked at the Virgilian allusion in the Semele story as a way of understanding Juno's role in the Metamorphoses, ${ }^{28} \mathrm{I}$ think we can also look at the legal allusion in the Tiresias narrative to understand Juno's changing role in both stories. As noted above, there is a classification of women under the lex Iulia de adulteriis, and Juno, when viewed with respect to this classification, is certainly not a positive exemplum. As Iuno she is married to Jupiter but she is not a materfamilias, having never produced a child with him (as Semele does). And it is Iuno who is declared by Tiresias to be more affected by voluptas than Jupiter (3.321-2). Given that sexuality under the Augustan regime is not about voluptas, the apparent topic under debate in the Tiresias scene, but about the preservation of noble families and Roman morality, which is achieved in the Semele scene, Iuno does not fare well in this section of the book. She is, essentially, a failed patrician woman. As Saturnia, though, Juno reclaims her divine status, inflicting upon mortals the kind of justice only gods can administer and thus setting right her role on the divine plane. Her anger is a Virgilian anger insomuch as it is an anger which could have only been achieved within a different political context, a time before the moral legislation.

Tiresias' punishment, his blinding, becomes all the more significant as well when placed into this historical context. Juno essentially makes Tiresias incapable of participating in Augustus' moral legislation because the legislation requires a witness, something which Tiresias cannot be once he is blinded. Tiresias' role as an arbiter (mediator) in a debate about sex, about the private realm, results in a punishment that makes him incapable of ever again being an arbiter (witness) in the public realm. Ovid's clever legal wordplay with the term arbiter - Tiresias loses the ability to be an arbiter by being an arbiter - marks a trend in the third book of the Metamorphoses in which mortals who witness the private lives of others, typically women, are punished in such a way that makes them incapable of ever revealing what they saw. Actaeon, for example, becomes a deer after seeing Diana bathe, a state in which Ovid explicitly states he can no longer speak (138-252); ${ }^{29}$ Semele is destroyed for having sex with Jupiter and the proof of this affair, Dionysus, is also almost destroyed (3.253-315); Echo loses her ability to speak, which she would use to keep Jupiter's affairs with the nymphs hidden from Juno (3.359-69);

28 - Consider the following parallel: si sum regina Iovisque et soror et coniunx, certe soror (Met. 3.265-6); ast ego, quae divom incedo regina, Iovisque et soror et coniunx (Aen. 1.46-7).

29 - ingemuit: vox illa fuit (3.202). 
and Pentheus is torn apart and killed after witnessing women engage in Bacchic rites (3.511-733). Each person who has witnessed a private act of sex or sexuality is punished in such a way so that they could never publicly reveal what they witnessed; the witnesses in a sense become the evidence which is destroyed, ensuring that private affairs remain private. The third book as whole, therefore, reverses the standard Roman procedure for the morality laws, punishing witnesses before they can punish those who have been witnessed. While I mentioned at the outset of this paper that the legal language marks the story of Tiresias as unique from the other narratives in the third book, I think we can now refine that point: Ovid's narration of the Tiresias myth permits us to see the allusions to legal reality behind the legal language, and this legal reality in turn is behind most of the other narratives in the third book.

These private affairs do not, of course, remain private. Ovid is the ultimate witness, revealing to his external reader all that has been seen, speaking for those who can longer speak. In doing so, Ovid positions his reader as the judge and jury, leaving it for them to decide whether the acts witnessed or the punishments administered are criminal or innocent, just or unjust. It is through Ovid's narration, which, as we have seen, focuses on the mutability of legal language, legal authority, and legal boundaries, that he can create his own sort of trial, asking his audience to offer their own sententiae on Tiresias' punishment and Augustus' moral legislation. While Habinek writes that in the Amores "Ovid seeks to reduce to absurdity the new legal specifications for proving illicit sexual behavior" (1998, 30), I think what we see here in Book Three of the Metamorphoses is more than a reductio ad absurdum. The story of Tiresias certainly pokes fun at the moral legislation: it presents a discussion about sex within a legal framework and throws into relief the very kind of debates which may have been occurring between jurists with the enforcement of the marriage laws. The story, though, is also the centerpiece of the book, directly connecting the intrusion of the public realm into the private realm to legal precepts and authority. Ovid's deployment of legal terminology in this passage represents more than the litigious atmosphere in Rome: Ovid's intervention into the poetic realm with his legal terminology mirrors Augustus' intervention into the private realm with this moral legislation.

The legal terms in the story of Tiresias are thus more significant than they may have initially appeared. Not only does Ovid use these terms to foster connections to contemporary practices in Rome, but the legal language in this central passage allows us to apply an overarching legal framework to rest of the third book. Most importantly, Ovid demonstrates in this passage the flexibility of much of Roman legal language. We saw, for example, how the term sententia, which has not so much dif- 
ferent meanings as different registers depending on the contexts in which it used, can mean one thing for Jupiter in his mock trial and something quite different for Juno, viewing the mock trial as a real judgment; the interpretation of the context by each god affects the valence of the term and their reaction to it. It is a similar situation for the term doctus, which means in its poetic contexts nothing more than a learned man, in its legal contexts a Roman jurist, and in its historical contexts the employment of such jurists by the emperor Augustus. When encountering legal language in Roman poets we should be careful, therefore, to determine just how 'legal' these terms are, when they are set legal phrases which can exist only a legal context and when they are multivalent terms that change in meaning depending on the contexts. We must ask where these terms gain their authority and the potential problems which can arise when authority or context is misconstrued.

In conclusion we can look at the language used to describe Tiresias' final metamorphosis into a vates, a prophet, to see how this approach to legal terminology can yield satisfactory results. Tiresias' prophetic utterances are described as responsa inreprehensa (3.340). Responsum is the official term for the legal decision of a jurist, but responsum can also mean a prophetic utterance. While we can simply say that Ovid's use of responsum here would have 'legal undertones' for his audience, such an analysis ignores why Ovid would want to suggest a legal framework. That responsum applies specifically to a juridical decision is significant for our reading of the passage; Tiresias has just been likened to a jurist, and so the use of responsa to describe Tiresias' prophecies thus links together the two roles of jurist and prophet. The verb sumere accomplishes the same kind of allusion, used as it is to describe Lirope when testing if Tiresias tells the truth (ratae temptamina sumpsit, 3.341), and Jupiter when taking Tiresias on as a mediator (arbiter hic igitur sumptus, 3.332). While responsa and sumere serve to connect Tiresias' new role as a prophet to his previous role as a judge, these terms also highlight once again the importance of context for determining the legal register of a term. Both of these terms within their contexts in the narrative have a primary sense which is poetic or popular. The legal valence is secondary and achieved only through allusion to the previous passage. In other words, the increasing use of specific legal language found in the Tiresias judgment passage becomes increasingly unspecified, broadening out again; the multivalent terms serve as a transition from a story filled with legal phrases back into a properly poetic context just as the narrative itself transitions us from the story of Tiresias to the story of Narcissus.

There is one final wordplay which we must take into consideration. I have focused most of my attention in this paper on Tiresias' changing 
legal roles, but we cannot ignore his more prominent role in Greek literature as a seer, a vates, and the new connotations the word vates has in Augustan poetry with the poet. ${ }^{30}$ Horace, in fact, describes the vates in his Ars Poetica as men who found cities, give laws, and establish public morality and religion, and it is the vates who first inscribes law onto wood (leges incidere ligno, 399). The poet, prophet, and lawgiver all engage in the dissemination of specialized knowledge and all employ a simple term like responsum with drastically different meanings based solely on the context in which they use it. Tiresias is, in this sense, a doublet for the poet Ovid in more ways than one. The roles each man adopts are based upon language, authority, and the importance of context for language to have the right authority. Indeed, both Tiresias and Ovid become men stuck between two lives, be it mortal and prophet or poet and exile, when they place text in the wrong context.

\section{Works Cited}

Balsley, K. Forthcoming. "Truthseeking and Truthmaking in Ovid's Metamorphoses 1.163-245." Law and Literature.

Barchiesi, A. 1997. The Poet and the Prince: Ovid and Augustan Discourse. Berkeley.

.Ed. 2005. Ovidio: Metamorfosi, Volume 1 (Libri I-II). Milan.

Bauman, R. A. 1980. The Leges iudiciorum publicorum and Their Interpretation in the Republic, Principate and later Empire. Berlin.

Csillag, P. 1976. The Augustan Laws on Family Relations. Budapest.

Coleman, K. M. 1990. "Tiresias the Judge: Ovid Metamorphoses 3.322-38." CQ 40.2:571-7.

Di Rocco, E. 2007. Io Tiresia: Metamorfosi di un Profeta. Rome.

Dugan, J. 2007. "Modern Critical Approaches to Roman Rhetoric," In W. J. Dominik and J. Hall, eds., A Companion to Roman Rhetoric. Malden, MA. 9-22.

Feeney, D. 1991. The Gods in Epic: Poets and Critics of the Classical Tradition. New York.

30 - As Newman (1967) has most thoroughly detailed, but also O'Hara (1990) and Lovatt (2007), the term vates is first used to describe a poet in Virgil's Eclogues and it then occurs throughout Horace, Propertius, and Tibullus. Ovid uses it with the most frequency and, in Newman's opinion, completely debases the original tension which existed when authors like Virgil and Horace first used the term selectively to refer to poets. Newman, in fact, jumps on the Roman poet Propertius' use of vates to describe Tiresias as a prophet (4.9.57) as a signpost for the devaluation of the term: "That the meaning could be shifted in this way from Roman actuality to Greek mythology is a proof of the manner in which the concept was gradually being emptied of its significance. It was one thing for Orpheus and Amphion to be vates, as poets and founders of civilisations. What claims in that direction had Tiresias?" (95). Ovid, I think, makes quite clear the claims Tiresias had. 
Fantham, E. 1983. "Sexual Comedy in Ovid's Fasti: Sources and Motivation." HSCP 87:182-216.

Frier, B. 1985. The Rise of Roman Jurists. Princeton.

Habinek, T. 1998. Politics of Latin Literature. Princeton.

Hardie, P. 1990. "Ovid's Theban history: the first 'anti-Aeneid?" CQ40: 224-35.

Hollis, A. S. 1994. "Rights of Way in Ovid (Heroides 20.146) and Plautus (Curculio 36)." CQ 44.2: 545-9.

Hopkinson, N., ed. 2001. Ovid: Metamorphoses Book XIII. Cambridge.

Horsfall, N. 1979. "Epic and Burlesque in Ovid, Met. viii.260ff." CJ 74:319-32.

Kajanto. I. 1961. Ovid's Conception of Fate. Turku.

Kenney, E. J. 1969. "Ovid and the Law.” YCS 21:248-9.

Knox, P. E. 1986. Ovid's Metamorphoses and the Traditions of Augustan Poetry. Cambridge.

Louden, B. 2005. "The Gods in Epic, or the Divine Economy." In J. M. Foley, ed., A Companion to Ancient Epic. Oxford.

Lovatt, H. 2007. "Statius, Orpheus, and the Post-Augustan Vates." Arethusa 40.2:145-63.

McGinn, T. 1998. Prostitution, Sexuality, and the Law in Ancient Rome. Oxford. . 2001. "Satire and the Law: the Case of Horace." PCPhS 47:81-102.

Milnor, K. 2005. Gender, Domesticity, and the Age of Augustus: Inventing Private Life. Oxford.

- 2007. "Augustus, History, and the Landscape of the Law." Arethusa 40:723.

Newman, J. 1967. The Concept of Vates in Augustan poetry. Collection Latomus, v. 89. Bruxelles.

O'Hara, J. 1990. Death and the Optimistic Prophecy in Vergil's Aeneid. Princeton. 1996. "Sostratus Suppl. Hell. 733: a lost, possibly Catullan-era Elegy on the Six Sex Changes of Tiresias." TAPA 126:173-219.

Prauscello, L. 2008. "Juno's Wrath Again: Some Virgilian Echoes in Ovid, Met. 3.253-315.” CQ 58.2.565-70.

Schiesaro, A. 2007. "Didaxis, Rhetoric, and the Law in Lucretius." In S. J. Heyworth ed., Classical Constructions: Papers in Memory of Don Fowler. Oxford. 63-90.

Talbert, R. J. A. 1984. The Senate of Imperial Rome. Princeton.

Tarrant, R. 2002. "Ovid and Ancient Literary History." In P. Hardie, ed., The Cambridge Companion to Ovid. Cambridge. 13-33.

Tuori, K. 2004. "The ius respondendi and the Freedom of Roman Jurisprudence." Revue internationales des droites de l'Antiquité 51:295-337.

Ugolini, G. 1995. Untersuchungen zur Figur des Sehers Teiresias. Tübingen. 
van Tress, H. 2004. Poetic Memory, Allusion in the Poetry of Callimachus and the Metamorphoses of Ovid. Leiden.

VerSteeg, R. and N. Barclay. 2003. "Rhetoric and Law in Ovid's Orpheus." Law and Literature 15.3: 395-420.

Wallace-Hadrill, A. 1997. "Mutatio morum." In T. Habinek and A. Schiesaro, eds., The Roman Cultural Revolution. Cambridge. 3-2. 
